\title{
EFEITOS DA FORMAÇÃO INICIAL NAS PRÁTICAS DE ENSINO DE ESCRITA DE UMA PROFESSORA DE LÍNGUA PORTUGUESA DO ENSINO FUNDAMENTAL ${ }^{1}$
}

\author{
Maria de Fátima Alves* \\ Fabiana Ramos**
}

\begin{abstract}
Resumo: Este artigo analisa os impactos da formação inicial sobre as práticas de ensino de escrita de uma professora egressa do Curso de Pedagogia de uma Instituição pública de ensino da Paraíba, com base nas noções de escrita como atividade sociodiscursiva e de gênero textual como entidade empírica de organização dos discursos. Para tanto, discute a contribuição das teorias sobre escrita e gêneros textuais para a formação inicial docente, a partir de relatos dessa professora sobre o seu processo de formação, bem como sobre uma proposta de produção de texto. A análise dos dados demonstra que a apropriação de conhecimentos sobre as teorias acerca da escrita situada e dos gêneros textuais pode favorecer o redimensionamento das práticas de ensino de escrita.
\end{abstract}

Palavras-chave: Formação Inicial. Escrita. Gêneros textuais.

\begin{abstract}
This article analyzes the impact of a pre-service teacher education program on the writing practices of an elementary school teacher from a Pedagogy Course, who teaches at a public school in the state of Paraíba. The rationale was based on the notions of writing as a socio-discursive activity and text genre as an empirical entity of discourse organization. To this end, the article discusses the contribution of theories related to writing and genres used at academic education, through that teacher's reports about her education process, as well as her text production proposal. The data analysis shows that the appropriation of knowledge about the theories of situated writing and genres may favor the resizing of the writing teaching practices.
\end{abstract}

Keywords: Academic Education. Writing. Text Genres.

\section{Introdução}

O trabalho com a escrita na escola por muito tempo limitou-se a propostas de atividades que pouco ou nada propiciavam ao aluno produtor de textos entender a escrita como uma prática social situada que se materializa em um determinado gênero de texto. Somente a partir das contribuições das teorias da escrita mais recentes, a exemplo daquelas advindas dos paradigmas sociocognitivo e sociointeracionista, e das teorias dos gêneros textuais, esse trabalho começou a tomar feições diferenciadas na sala de aula.

Nesse processo de mudanças, a formação docente inicial tem sido fundamental, à medida que pode promover espaços de estudo e reflexão sobre o lugar da escrita na escola, a partir da discussão sobre concepções de escrita e de texto, bem como sobre as implicações das práticas de ensino pautadas em tais concepções. Desse modo, considerando a importância do processo formativo inicial para a construção da identidade do professor de língua, neste trabalho, objetivamos analisar os efeitos da formação inicial sobre as práticas de ensino de escrita de uma professora egressa do Curso de Pedagogia de uma Instituição pública de ensino.

\footnotetext{
${ }^{1} \mathrm{O}$ presente trabalho consiste num recorte de uma pesquisa (ALVES, 2013-2014) vinculada ao PIBIC/CNPq, cujo objetivo geral era investigar as práticas de ensino de escrita de professores do Ensino Fundamental de escolas públicas de municípios paraibanos.

* Doutora em Linguística pela UFPE, professora da Unidade Acadêmica de Educação (UAEd/UFCG) e do Programa de Pós-Graduação em Linguagem e Ensino (UFCG). Endereço eletrônico: fatima.uaed@ gmail.com

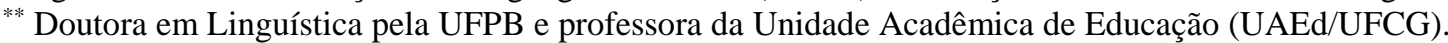


Para alcançar o objetivo pretendido, em primeiro lugar, discutimos a contribuição das teorias sobre escrita e gêneros textuais para o trabalho com a produção textual no contexto da sala de aula. Em um segundo momento, refletimos sobre a formação docente inicial e sua contribuição para a prática de ensino, a partir dos relatos da professora em foco sobre o seu processo de formação, bem como de uma proposta de produção textual elaborada por ela. Por fim, apresentamos nossas palavras finais.

\section{O ensino de escrita no Ensino Fundamental: desafios e possibilidades}

Os discursos que circulam sobre a escrita e o trabalho com tal atividade no espaço da sala de aula, em especial na Educação Básica, têm sido objeto de estudo de muitas pesquisas (GERALDI, 1984; PÉCORA, 1999; REINALDO, 2002; ANTUNES, 2003; BONINI, 2006; BRITO, 2009; MARCUSCHI e LEAL, 2010, dentre outras), na área da linguagem, nas últimas décadas do século passado e nos dias atuais. Entretanto, os efeitos dessas discussões, amplamente difundidas no âmbito acadêmico, chegam a passos lentos aos professores do Ensino fundamental. Prova disso é que muitos dos docentes, em pleno século XXI, continuam orientando atividades de escrita com foco nas habilidades para o domínio da língua culta e não como um processo interativo que exige finalidade, interlocutores definidos, conhecimento da esfera social e do gênero textual a ser definido etc. A demanda do texto escrito a ser redigido no contexto escolar "costuma atrelar-se a objetivos pedagógicos que desconsideram as funções e o modo de produção dos textos no uso social da linguagem" (MARCUSCHI e LEAL, 2009, p. 130).

Assim, trabalhar a escrita como uma prática social situada tem se tornado um desafio tanto para os professores que têm dificuldade na orientação de um trabalho sistemático que considere as condições de produção textual, quanto para os alunos, que em função das cobranças de atividades, muitas vezes sem sentido, adquirem traumas sobre a prática da escrita.

Para vencer os desafios citados, acreditamos ser necessário que os docentes se apropriem de saberes teóricos sobre as teorias acerca da escrita e sobre os gêneros textuais, a fim de posteriormente mobilizarem estes saberes na sala de aula de forma producente e que os alunos se conscientizem de que devemos escrever em função de uma necessidade de uso da língua e não simplesmente para cumprir uma tarefa escolar exigida pelo professor.

Quanto às teorias sobre a escrita, é fundamental que o professor compreenda que existem diversas concepções sobre o ato de escrever, a exemplo da escrita com foco na língua, cuja preocupação maior do ato de escrever trata-se do domínio das normas gramaticais, vocabulário, uso de sinais de pontuação, concordância, regência etc (KOCH; ELIAS, 2006). Nesta perspectiva, só quem conhece bem as regras da língua poderá escrever bem. Subjacente a esta concepção de escrita, encontra-se uma concepção de linguagem como um sistema pronto, acabado, devendo o escritor se apropriar desse sistema e de suas regras. $\mathrm{O}$ texto passa a ser compreendido meramente como produto de uma codificação realizada pelo escritor para ser decodificado pelo leitor.

Já dentro da concepção de escrita com foco no escritor, 'escrever é expressar o pensamento no papel' (KOCH; ELIAS, op. cit., p. 33). Trata-se de uma atividade por meio da qual aquele que escreve expressa o seu pensamento, suas intenções, sem levar em conta as experiências e os conhecimentos do leitor ou a interação que envolve este processo. Neste contexto, o texto é visto como produto lógico do pensamento do escritor.

A escrita com foco na interação, por outro lado, é vista como produção textual, cuja realização exige do produtor a ativação dos conhecimentos e a mobilização de várias 
estratégias. O produtor de textos, guiado pelo princípio interacional da linguagem como prática social situada, reflete sobre a própria escrita, contemplando os objetivos do texto, o leitor, o registro linguístico e o gênero textual. Com base numa concepção dialógica de língua, segundo Koch e Elias (2006), entende-se que tanto aquele que escreve, quanto aquele para quem se escreve são vistos como atores/construtores sociais, sujeitos ativos que dialogicamente - se constroem e são construídos no texto, que é considerado um evento comunicativo para o qual concorrem aspectos linguísticos, cognitivos, sociais, interacionais.

Nessa perspectiva, ainda conforme o ponto de vista das autoras acima citadas, a escrita é uma atividade que demanda da parte de quem escreve muitas estratégias: a) ativação de conhecimentos sobre os componentes da situação comunicativa; b) seleção, organização e desenvolvimento das ideias, de modo a garantir a continuidade do tema e sua progressão; c) balanceamento entre informações explícitas e implícitas, entre informações novas e dados, levando em conta o compartilhamento de informações com o leitor e o objetivo da escrita; e d) revisão da escrita ao longo de todo o processo. Essas estratégias se alinham com a ideia de que elaborar um texto escrito é uma tarefa cujo sucesso não se completa simplesmente pela codificação das ideias ou das informações através de sinais gráficos. Produzir um texto supõe várias etapas interdependentes e intercomplementares, que vão desde o planejamento do que se vai escrever até a revisão do texto.

Como vemos, a concepção interacionista/dialógica de escrita revela que tal atividade trata-se de processo que exige reflexão crítica, não resulta apenas do uso ou domínio do código, nem tão somente das intenções do escritor. Defendemos esta concepção porque reconhecemos o caráter dialógico da escrita como sendo uma prática social situada, na qual se escreve para alguém, em uma dada circunstância, para atender a um objetivo específico.

Entendemos, como Geraldi (1997), que a produção de textos deve ser o ponto de partida de todo o processo de ensino-aprendizagem da língua. Isso porque é no texto que a língua se revela em sua totalidade, quer enquanto conjunto de formas e de seu reaparecimento, quer enquanto discurso que remete a uma relação intersubjetiva constituída no próprio processo de enunciação, marcada pela temporalidade e suas dimensões. $\mathrm{Na}$ produção de discursos, ressalta o autor, o sujeito articula aqui e agora um ponto de vista sobre o mundo que, vinculado a uma certa formação discursiva, dela não é decorrência mecânica, sendo seu trabalho mais do que mera reprodução: se fosse apenas isso, os discursos seriam idênticos, independentemente de quem e para quem resultam.

Para se produzir um texto em qualquer modalidade, segundo Geraldi (op. cit.), é preciso que: se tenha o que dizer; se tenha uma razão para se dizer o que se tem a dizer; se tenha para quem dizer o que se tem a dizer; o locutor se constitua como tal enquanto sujeito que diz o que diz para quem diz; e se escolham as estratégias para realizar.

A perspectiva acima defendida por Geraldi, desde a metade dos anos 80 do século passado, para se trabalhar a produção de textos, considerando o contexto de produção e de circulação dos mesmos, nos faz concluir que é inviável levar os alunos a produzirem simples "redações", como meros produtos escolares destituídos de intenções, objetivos, função social. Devemos incentivar os docentes a levarem os alunos a produzir textos que tenham sentido para eles, que se aproximem dos usos extra-escolares, com função específica e objetivos claros.

Assumindo esta posição, apostamos em um ensino mais produtivo de escrita que leva em consideração o próprio processo de produção de textos e que vê a sala de aula, assim como as esferas da comunicação humana, como espaços de interação verbal.

Nessa mesma linha de discussão, Marcuschi e Leal (2009) ressaltam que no espaço extra-escolar, ao produzir um texto escrito, o autor, via de regra, tem em vista, mesmo que, inconscientemente, as condições de produção e de circulação textuais. Leva em conta para 
que escrever, quando, sobre o que e com que objetivo se escreve. Esses fatores, conforme as autoras citadas, definem tanto os gêneros textuais mais adequados ao contexto sociocomunicativo, quanto o tom que deseja imprimir ao seu texto (formal ou informal, irritado ou benevolente, entre outras possibilidades). As experiências do escritor, em diferentes situações de uso da língua, sem dúvida, influenciam nas decisões do formato do texto, da linguagem a ser usada e estratégias a serem adotadas. Daí a diferença entre uma carta de reclamação, uma nota de pesar ou um convite de aniversário.

Antunes (2003), ao refletir sobre o problema do ensino de escrita no contexto escolar, mostra que o que existe de fato é a prática de uma escrita mecânica e periférica centrada, inicialmente, nas habilidades motoras de produzir sinais gráficos e, mais adiante, na memorização pura e simples de regras ortográficas: para muita gente, não saber escrever ainda equivale a escrever com erros de ortografia, ou seja, a prática de uma escrita artificial e inexpressiva, realizada em exercício de criar lista de palavras soltas ou ainda de formar frases. Tais palavras e frases isoladas, desvinculadas de qualquer contexto de uso da linguagem, tornam-se vazias do sentido e das intenções com que os interlocutores dizem o que pretendem. Além do mais, esses exercícios de formar frases soltas afastam os alunos daquilo que eles fazem quando interagem com outros em seu convívio social, que é construir textos, com unidade, com começo, meio e fim, para expressar suas intenções em contextos específicos de comunicação.

Concordamos plenamente com o ponto de vista de Antunes (2003), bem como com sua visão de que é na escola onde as pessoas "exercitam" a linguagem ao contrário, ou seja, a linguagem que não diz nada. Nessa prática vazia, os princípios básicos da linguagem são violados, porque o que se diz é reduzido a uma sequência de frases desligadas, umas das outras, sem qualquer perspectiva de progressão textual e sem responder a qualquer tipo particular de contexto social.

Para virar esta página, entendemos que é fundamental levar em consideração as condições de produção e circulação dos textos, já discutidas neste artigo, e trabalhar de forma sistemática com os gêneros textuais.

No nosso entender, o conhecimento dos fatores da textualidade por si só não é responsável pela escrita de um bom texto e saber que a escrita trata-se de um processo que presume planejamento revisão e reescrita também não esgotam as possibilidades de se escrever um texto bem escrito. É preciso considerar outros aspectos externos ao processo de escrita propriamente dito, como, por exemplo, considerar a esfera social, o gênero a ser produzido, objetivos, suporte etc.

Os gêneros são textos que encontramos no nosso dia a dia e que apresentam padrões sociocomunicativos definidos por composições funcionais, objetivos enunciativos e estilos concretamente realizados na integração de forças históricas, sociais, institucionais e étnicas. (MARCUSCHI, 2008, p.155). Usamos os gêneros textuais para agirmos linguisticamente no mundo em diferentes contextos comunicativos.

Podemos afirmar a partir de Bakhtin (1997) que os gêneros textuais se organizam em função de um contexto sócio-histórico, de um objetivo que norteia a situação comunicativa, de uma estrutura composicional e de marcas linguísticas próprias de cada gêneros, denominadas de estilo.

Para trabalharmos com a produção de gêneros textuais no espaço da sala de aula, consideramos importante que atentemos para o contexto de produção, definido como um conjunto de parâmetros que podem exercer sua influência sobre a forma como um texto é organizado (BRONCKART, 1999, p. 93).

Dentre os fatores que influenciam a organização do texto, Bronckart (1999) destaca o contexto físico e social. O físico pode ser definido por quatro parâmetros: o lugar de 
produção, lugar físico em que o texto é produzido; o momento de produção, a extensão do tempo durante a qual o texto é produzido; o emissor, a pessoa que produz fisicamente o texto; o receptor, a pessoa que recebe concretamente o texto.

No segundo plano, a produção do texto, segundo Bronckart (op. cit, p. 94), inscrevese no quadro de uma formação social e, mais precisamente, no quadro de uma forma de interação comunicativa que implica o mundo social (normas, valores, regras) e o mundo subjetivo (imagem que o agente dá de si ao agir). Esse contexto sociossubjetivo contempla, segundo o autor, quatro parâmetros: 1) o lugar social, que diz respeito ao quadro de qual formação social, de qual instituição o texto é produzido (escola, família, mídia etc.); 2) a posição social do emissor, que papel social o emissor/enunciador desempenha na interação em curso; 3 ) a posição social do receptor, papel atribuído ao receptor do texto (papel de aluno, colega, etc.); 4) o objetivo, o qual corresponde aos efeitos do texto causados no destinatário.

Toda a reflexão feita até o momento focalizando tanto a problemática do ensino de escrita na escola quanto a relevância de se trabalhar a escrita em uma perspectiva dialógica de linguagem, considerando as condições de produção e de recepção dos gêneros textuais (o gênero a ser trabalhado, o tema a ser desenvolvido, o leitor para quem o texto se destina, o objetivo, o registro linguístico a ser usado) aponta para a importância de nos cursos de formação inicial, em especial Letras e Pedagogia, haver uma devida correlação entre saberes teóricos e práticos que favoreçam aos egressos de tais cursos competências para mediar a escrita na escola de forma producente. Tendo em vista tal relevância, na seção a seguir, discutiremos a formação docente inicial, focando-nos na avaliação de uma professora de Língua Portuguesa das contribuições do processo formativo para o seu trabalho com a escrita na sala de aula.

\section{A formação do professor de língua portuguesa para o ensino de escrita: investigando os efeitos}

A formação do professor de língua materna tem-se constituído nas últimas décadas em uma preocupação dos linguistas, materializada, sobretudo nos estudos vinculados à Linguística Aplicada (KLEIMAN, 2001, 2007; MOITA LOPES, 2002; BOHN, 2005; CELANI, 2002; BUENO, LOPES e CRISTOVÃO, 2013). A despeito da diversidade de enfoques assumidos em tais estudos, a compreensão da necessidade de cursos de formação docente inicial ou continuada que tomem a leitura e a escrita como práticas sociais e o gênero textual como ponto de partida e de chegada dessas práticas parece ser um aspecto recorrente.

Nessa direção, Kleiman (2007) destaca que os cursos de formação docente devem necessariamente funcionar como um espaço de, paulatinamente, efetivar a desideologização da leitura e da escrita, uma vez que, para ela, a naturalização da escrita oculta o fato de que os usos da língua não são neutros, guardando relações de poder na sociedade, o que não deve ser desconsiderado pelo professor no trabalho com o texto, sob pena de contribuir para a desigualdade e a exclusão social. Assim, a autora chama a nossa atenção para a necessidade de que os professores em formação atentem para a dificuldade dos alunos em realizar atividades de uso da língua que não façam sentido para eles, a exemplo da solicitação da leitura e da produção de um determinado gênero textual descolada de seu contexto de uso.

A propósito, Antunes (2005) lembra-nos sobre a necessidade de que o professor planeje suas propostas de produção escrita a partir da compreensão de que escrever é uma atividade contextualizada e, portanto, situada em um dado momento, em um espaço e inserida em algum evento cultural. Isso implica dizer que não escrevemos do mesmo modo em contextos de uso diferentes. 
Nessa perspectiva, com base em Heath (1983), Kleiman (2007) defende que os cursos de formação devem primar por formar nos graduandos um olhar de etnógrafo, voltado para a observação por esses futuros professores daquilo que torna suas turmas heterogêneas, as suas práticas sociais de origem, o que poderá auxiliar esses profissionais a diagnosticar, planejar e avaliar os processos de ensino e aprendizagem. Conhecendo os alunos e suas bagagens culturais, segundo a autora, o professor terá maior facilidade de promover atividades que considerem efetivamente o aluno, suas potencialidades e limitações.

No plano da escrita, um trabalho de formação docente feito nessa direção implica discutir com os alunos-professores a necessidade de propiciarem a seus futuros alunos oportunidades de utilizarem a língua de forma dialógica e situada, o que exige deles, segundo Bunzen (2006, p. 157), "criar situações e estratégias em que os alunos utilizem os gêneros textuais em diferentes situações", sempre associados a seus contextos de uso.

Assim sendo, o curso de Pedagogia da UFCG, nas últimas décadas, tem assumido como um de seus compromissos a formação de professores que possam atuar na Educação Infantil e anos iniciais do Ensino Fundamental a partir dos pressupostos para o trabalho com a língua materna aqui apresentados. Especificamente em alguns componentes curriculares que focam o trabalho com a linguagem, a exemplo de Língua materna na Educação Infantil e nos anos iniciais do Ensino Fundamental, o trabalho com a escrita tem sido visto como um processo de interação, no qual é fundamental a situação comunicativa que envolve a produção de um determinado gênero, bem como o olhar do outro para a revisão e reescrita textuais. Com base nessa compreensão, o componente, anteriormente citado, objetiva trabalhar a escrita a partir de textos teóricos que a discutem e da análise e elaboração de propostas de produção de textos fundamentadas numa concepção dialógica de linguagem.

As produções aqui avaliadas são frutos do trabalho com o ensino de escrita de uma professora formada pelo referido curso a partir da perspectiva já apresentada. Essa professora concluiu seu curso em 2008 e participou da pesquisa que deu origem a este artigo.

Uma primeira produção por nós analisada é um relato da professora a respeito de sua percepção sobre o seu processo formativo. $\mathrm{O}$ relato em análise foi produzido por esta professora a partir de nossa solicitação, tendo em vista a reflexão sobre os efeitos do trabalho de formação inicial na sua prática de ensino de língua materna. A professora, devidamente esclarecida sobre os objetivos deste trabalho, consentiu a utilização do seu relato, bem como disponibilizou-nos também o relato de uma proposta de produção escrita elaborada por ela para análise e divulgação científica. Vejamos:

Iniciei o curso de Licenciatura em Pedagogia no ano de 2003, em uma Universidade pública, no segundo semestre. Até a conclusão, ocorrida no ano de 2008, cursei várias disciplinas, dentre elas, as disciplinas que discutiam os conteúdos da área de linguagem: Língua Portuguesa I, Língua Portuguesa II e Metodologia da Língua Portuguesa. As discussões teóricas realizadas nessas três disciplinas foram de grande valia para minha formação, para o planejamento das estratégias didáticas para ensino da Língua Portuguesa (doravante LP) nos anos finais do ensino fundamental ${ }^{2} \mathrm{e}$, consequentemente, dar mais sentido às aulas e conteúdos de LP para os alunos, até mesmo para os mais desmotivados. Tudo isso porque, durante tais disciplinas, tive a oportunidade de ler, discutir, refletir acerca de temas como: Letramento e Letramento e alfabetização, Teorias da leitura, Estratégias de leitura, Teorias de ensino da escrita, As condições de produção textual/escrita situada (Geraldi), o estudo dos gêneros textuais

\footnotetext{
${ }^{2}$ A professora atua nos anos finais do Ensino Fundamental porque também cursou a Licenciatura em Letras.
} 
baseado nos apontamentos do Grupo de Genebra (Schneuwly e Dolz), entre outros. Estes dois últimos pontos foram, para mim e minha formação enquanto professora de Língua Portuguesa, as discussões mais relevantes para nortear o trabalho com a escrita em sala de aula dando, de certa forma, sentido às produções textuais realizadas pelos alunos em sala de aula, já que tais perspectivas apontam para um trabalho que leve em conta e seja significativo para o aluno e contribua para um domínio efetivo da língua, possibilitando seu uso adequado também fora do espaço escolar. Assim, o que pude inferir das discussões em sala de aula é que a aprendizagem da escrita deve estar de acordo com a condição específica da situação de comunicação em que se encontram os sujeitos, seja oralmente ou por escrito. Dessa maneira, após estudar essas ideias durante as disciplinas citadas, redirecionei a forma de ensinar e aprender a escrita em sala de aula, levando o aluno a refletir sobre os objetivos e finalidades daquela produção, dandolhe condições para que tenham competência de produzir os diversos gêneros estudados também fora da escola. Tal percepção ficou mais clara para mim somente após conhecer e discutir academicamente tais teorias, pois, anteriormente a essas disciplinas, tive a oportunidade de lecionar LP para turmas do ensino fundamental II (do $6^{\circ}$ ao $8^{\circ}$ ano), no ano de 2006. Durante essa experiência no que concerne ao trabalho com a escrita em sala de aula, o ensino foi pautado basicamente em produções textuais sugestionadas pelo livro didático, descontextualizadas, sem propósito comunicativo, servindo praticamente para "cumprir tabela". Também, durante essa experiência, a produção de gêneros textuais quase não existiu, pois ainda seguia aquele modelo de escrita baseado nas tipologias textuais, ou seja, os alunos eram convidados a produzir, textos dissertativos ou descritivos, pequenas narrativas, sem se levar em consideração as condições de produção textual, com temas escolhidos aleatoriamente, com uma única correção (não trabalhava com a reescrita), ou seja, ainda não entendia a escrita como um processo. Contudo, após estudar as teorias já citadas, compreendi o equívoco que cometi durante aquele período e entendi porque produzir um texto era/foi algo tão penoso para meu aluno. Hoje, depois de concluída minha formação em pedagogia, continuo lecionando para turmas do $6^{\circ}$ ao $8^{\circ}$ ano do ensino fundamental II regular, porém com outro direcionamento nas aulas de LP. Faço a escolha dos gêneros textuais previamente a serem trabalhados em cada turma; discuto com os alunos sobre a finalidade desse gênero e seu papel na sociedade; quais são as condições de produção de cada um; sua estrutura; situação comunicativa; os recursos linguísticos melhor adequados para sua produção etc. Também passei a trabalhar com a produção textual direcionada, muitas vezes buscando uma simulação de uso desse gênero de maneira que se assemelhe o mais possivelmente com o seu uso real, fora da escola. Outro aspecto importante, o de entender a escrita como processo, foi primordial, pois deixei de trabalhar com a ideia de uma única produção (somente a produção inicial bastava), e introduzi a prática da reescrita dos textos, para que assim o aluno possa compreender que a escrita não é um dom, na maioria das vezes, e que precisa ser exercitada. Dessa maneira, os temas, autores, perspectivas etc., trabalhados durante a disciplina representou uma mudança de postura e redimensionou minha prática em sala da aula.

Podemos constatar no relato anteriormente apresentado a relevância das disciplinas cursadas pela professora na sua formação inicial para a reflexão sobre os aspectos teóricos 
estudados, bem como para sua prática de ensino, no planejamento de estratégias para o agir docente.

No que tange especificamente os pressupostos teóricos para o trabalho com a escrita, observamos que a professora destaca em seu relato as condições de produção textual, a escrita situada e o estudo dos gêneros textuais como aspectos sobre os quais a discussão durante o processo formativo foi essencial para que pudesse dar sentido às produções dos seus alunos, a partir da compreensão de que o ensino/aprendizagem da escrita deve considerar a situação comunicativa na qual se insere a produção de determinado gênero textual:

Estes dois últimos pontos foram, para mim e minha formação enquanto professora de Língua Portuguesa, as discussões mais relevantes para nortear o trabalho com a escrita em sala de aula dando, de certa forma, sentido às produções textuais realizadas pelos alunos em sala de aula, já que tais perspectivas apontam para um trabalho que leve em conta e seja significativo para o aluno e contribua para um domínio efetivo da língua, possibilitando seu uso adequado também fora do espaço escolar. Assim, o que pude inferir das discussões em sala de aula é que a aprendizagem da escrita deve estar de acordo com a condição específica da situação de comunicação em que se encontram os sujeitos, seja oralmente ou por escrito.

Assim, é possível vislumbrarmos no relato em análise uma adesão da professora à concepção de escrita como uma atividade que está estreitamente relacionada à situação comunicativa na qual se insere e como prática social que se exerce também no espaço fora da sala de aula. Nesse sentido, a professora, ao destacar a importância de dar sentido às práticas de escrita no interior da escola, contribui para efetivar a desideologização da escrita em sua prática, como defende Kleiman (2007).

A professora evidencia também em seu relato um processo de reconfiguração de sua prática de ensino da escrita que, segundo ela, anteriormente à formação docente inicial, estava calcada nas propostas de produção de textos sugeridas pelos livros didáticos, por vezes, descontextualizadas e sem um propósito comunicativo definido. Para além disso, o trabalho sistemático com os gêneros textuais ainda não existia, estando sua prática voltada à produção de tipos de textos:

Também, durante essa experiência, a produção de gêneros textuais quase não existiu, pois ainda seguia aquele modelo de escrita baseado nas tipologias textuais, ou seja, os alunos eram convidados a produzir, textos dissertativos ou descritivos, pequenas narrativas, sem se levar em consideração as condições de produção textual, com temas escolhidos aleatoriamente, com uma única correção (não trabalhava com a reescrita), ou seja, ainda não entendia a escrita como um processo.

A ausência da compreensão da escrita como um processo, conforme ela, também não lhe permitia propiciar a revisão e a reescrita dos textos produzidos pelos alunos. Segundo a autora, é a partir do processo formativo que sua prática no tempo presente se reconfigura:

Hoje, depois de concluída minha formação em Pedagogia, continuo lecionando para turmas do $6^{\circ}$ ao $8^{\circ}$ ano do ensino fundamental II regular, porém com outro direcionamento nas aulas de LP. Faço a escolha dos gêneros textuais previamente a serem trabalhados em cada turma; discuto com os alunos sobre a finalidade desse gênero e seu papel na sociedade; quais são as condições de produção de cada um; sua estrutura; situação 
comunicativa; os recursos linguísticos melhor adequados para sua produção etc. Também passei a trabalhar com a produção textual direcionada, muitas vezes buscando uma simulação de uso desse gênero de maneira que se assemelhe o mais possivelmente com o seu uso real, fora da escola. Outro aspecto importante, o de entender a escrita como processo, foi primordial, pois deixei de trabalhar com a ideia de uma única produção (somente a produção inicial bastava), e introduzi a prática da reescrita dos textos, para que assim o aluno possa compreender que a escrita não é um dom, na maioria das vezes, e que precisa ser exercitada.

Tal processo de reconfiguração se atualiza numa prática agora voltada para a produção de um determinado gênero a partir de condições que consideram a situação comunicativa, a sua estruturação e propósito comunicativo, além da possibilidade de reescrever a primeira versão do texto em busca de seu aprimoramento.

Assim sendo, constatamos que a professora revela em seu relato os efeitos dos estudos promovidos durante a formação inicial no que diz respeito, mais especificamente, à abordagem da escrita no contexto do Ensino Fundamental, evidenciando a importância da construção de saberes nesse processo para a assunção de concepções e práticas de ensino de escrita pelo professor em formação.

Na seção seguinte, analisamos o relato de uma proposta de escrita produzida pela professora, com a perspectiva de compreender como suas concepções teóricas a respeito da produção escrita se atualizam na sua prática de ensino.

\section{Ecos da formação inicial docente no trabalho com a escrita}

O texto que analisamos a seguir consiste no relato ${ }^{3}$ detalhado da professora participante de nossa pesquisa do desenvolvimento de uma proposta de escrita planejada por ela do gênero textual rótulo:

Relato do desenvolvimento de uma proposta de Ensino de Escrita para o $6^{\mathbf{0}}$ Ano do Ensino
Fundamental
$1^{\text {o }}$ passo:
- Discuti com os alunos, previamente (5 minutos finais da aula no dia anterior), sobre o gênero a ser
estudado. Apresentei o rótulo como um recurso muito benéfico para o consumidor na escolha
correta e consciente dos produtos que consome, pois apresenta informações importantes que são
decisivas no momento de escolher o que comprar, porque apresenta informações como as
características do produto, o peso, o nome, data de validade, etc. Além do mais, alertei para o fato
de ser uma das principais estratégias de marketing para o comércio dos produtos de uma maneira
geral, pois através dele o fabricante pode informar, persuadir e vender a sua produção.Em seguida,
pedi que todos retirassem das mochilas os lanches que haviam trazido de casa para o horário do
recreio. Alguns trouxeram produtos industrializados (refrigerante, sucos engarrafados, biscoitos,
salgadinhos, etc.), e a partir desses produtos indaguei se eles sabiam o nome daquele papel que vem
envolto dos produtos ou das embalagens. Depois fizemos uma rápida leitura coletiva de dois
produtos do lanche deles, destacando qual era o produto, nome do produto, nome do fabricante,
peso. Em seguida, pedi para que eles trouxessem embalagens de produtos de casa, que fizesse parte
do dia a dia deles ou da família. Nesse caso, a tarefa de casa para os alunos foi trazer rótulos de

\footnotetext{
${ }^{3} \mathrm{O}$ relato foi solicitado por nós, pesquisadoras, tendo em vista o acompanhamento das práticas de ensino de escrita da professora participante de nossa pesquisa.
} 
diferentes alimentos e produtos de limpeza/higiene.

$\underline{2^{\circ} \text { passo: }}$

- Pedi que cada um colocasse a embalagem que trouxeram de casa em suas carteiras e em seguida comecei a discussão norteada pelas seguintes perguntas: para que vocês acham que serve um rótulo de embalagem? Vocês já haviam parado para olhar/ler rótulos de embalagens em outra ocasião? Para quem vocês acham que se destinam os rótulos de cada produto? O que acham das informações que estão presentes nos rótulos? Consideram importantes? Quem vocês acham que elaboram esses rótulos? Porque os produtos precisam de rótulos? Por que há tantas informações? Qual a importância dessas informações para o consumidor?

$\underline{3^{\circ} \text { passo: }}$

- Coletivamente, elencamos as características do gênero, como este se estrutura. Isso foi perguntado à turma que apresentou as seguintes informações:

Estrutura: Linguagem verbal e não verbal; o gênero apresenta-se com letras/palavras/ilustrações bem chamativos; slogan; designe chamativo; predomínio da linguagem formal, etc.

Características: nome do produto; slogan (subtítulo); peso/quantidade/volume; data de fabricação e validade; nome do fabricante; instruções de uso; ingredientes/fórmula/composição; tabela de informações nutricionais/ambientais; registro/certificado; CNPJ; SAC (serviço de atendimento ao cliente); nome e endereço do fabricante; código de barras.

Obs: as informações acima foram todas destacadas pelos alunos, a partir da leitura dos rótulos que trouxeram, enquanto eu escrevia no quadro.

$\underline{4^{\circ} \text { passo: }}$

Expliquei aos alunos a diferença entre produto e marca.

Produto: é o que está dentro da embalagem. Exemplo: sabão líquido.

Marca: é o nome que identifica, caracteriza o produto, ou seja, o sabão. Exemplo: Limpol.

Pedi aos alunos que anotassem o produto e a marca dos produtos que trouxeram.

Depois que analisaram os rótulos promovi uma socialização sobre produto e marca.

\section{$\underline{5^{\circ} \text { passo: }}$}

- Em seguida, pedi aos alunos que as separassem da seguinte forma: • Produtos alimentícios (milho verde, leite condensado, ervilha e outros); • Bebidas (refrigerante, leite, suco e outros); • Produtos de limpeza (sabão em pó, amaciante e outros); • Produtos de beleza (shampoo, condicionador, creme de pele, sabonete e outros), formando grupos.

$\underline{6^{\circ} \text { passo: }}$

- Cada aluno analisou o rótulo que trouxe, identificando quais os dados que estavam presentes em todos os produtos: Data de validade, data de fabricação, código de barra, composição do produto (ingredientes), medida do produto, entre outros.

Em seguida, cada um elaborou uma ficha com as informações do rótulo do produto escolhido por ele.

$\checkmark \quad$ Nome do produto e Marca.

$\checkmark$ Data de fabricação e Data de validade.

$\checkmark$ Medida.

$\checkmark$ Código de barra.

$\checkmark$ Composição do produto.

$\checkmark$ Endereço do fabricante; 


$\quad \checkmark \quad \begin{aligned} & \text { Instruções de uso, etc. Também elencaram todas as outras informações que eles mesmos } \\ & \text { destacaram na atividade anterior. }\end{aligned}$
$\underline{7^{\text {o }} \text { passo: }}$
- Nessa aula cada aluno escolheu uma embalagem, retirou o rótulo e criou o seu próprio produto e
rótulo, apenas aproveitando a caixa ou o formato da embalagem. Foi pedido que eles inventassem
um produto (como se fossem os fabricantes) e utilizassem os materiais para criação de um rótulo
que deverá conter as informações já elencadas por eles e que fossem possíveis de inserir na arte
gráfica.
- Nesse momento chamei a atenção que a ilustração, organização, linguagem, nome do produto,
etc., são importantes para chamar a atenção dos consumidores, e que eles pensassem se, caso
fossem eles a comprar aquele produto, se comprariam pela embalagem que estavam vendo.
$8^{\text {o passo: }}$
- Socialização coletiva: cada aluno apresentou o seu produto para os colegas da turma, indicando
que era um produto novo que chegou ao mercado daquela cidade. Assim, eles apresentavam o
produto que criaram, mostravam aos alunos a embalagem (com o rótulo criado por eles) e faziam a
propaganda do que "estavam vendendo".

A proposta de ensino de escrita, acima apresentada, sobre o trabalho com o gênero textual rótulo, a nosso ver, demonstra os ecos da formação inicial da professora e a sua competência no sentido de mobilizar saberes da área de linguagem, a exemplo das teorias sobre gêneros textuais, entendidos como "entidades sócio-discursivas e formas de ação social incontornáveis em qualquer situação comunicativa" (MARCUSCHI, 2002, p. 19), e sobre o ensino de escrita, considerando tal atividade como prática social situada e como um processo que leva em conta as condições de produção textual (o gênero a ser trabalhado, o tema a ser desenvolvido, o leitor para quem o texto se destina, o objetivo, o registro linguístico a ser usado).

A título de ilustração sobre a exploração bem sucedida no que concerne ao trabalho com gêneros textuais no espaço da sala de aula, podemos destacar o $2^{\circ}$ e o $3^{\circ}$ passo do relato da proposta trabalhada, nos quais são feitos questionamentos em torno da constituição do gênero textual em estudo (Rótulo) em seus aspectos estruturais, temáticos e estilísticos. Os questionamentos suscitam a discussão sobre o papel social do gênero, sobre suas condições de produção, conduzindo os alunos a refletirem sobre a importância de saber quem escreve o gênero, para quem escreve, com qual propósito se escreve, onde irá circular etc. Vejamos:

"Pedi que cada um colocasse a embalagem que trouxeram de casa em suas carteiras e em seguida comecei a discussão norteada pelas seguintes perguntas: para que vocês acham que serve um rótulo de embalagem? Vocês já haviam parado para olhar/ler rótulos de embalagens em outra ocasião? Para quem vocês acham que se destinam os rótulos de cada produto? O que acham das informações que estão presentes nos rótulos? Consideram importantes? Quem vocês acham que elaboram esses rótulos? Porque os produtos precisam de rótulos? Por que há tantas informações? Qual a importância dessas informações para o consumidor?"'(2 $2^{\circ}$ Passo)

"Coletivamente, elencamos as características do gênero, como este se estrutura [...]o gênero apresenta-se com letras/palavras/ilustrações bem chamativos; slogan; designe chamativo; predomínio da linguagem formal, etc.Características: nome do produto; slogan (subtítulo); peso/quantidade/volume; data de fabricação e validade; nome do fabricante; 
instruções de uso; ingredientes/fórmula/composição; tabela de informações nutricionais/ambientais; registro/certificado; CNPJ; SAC (serviço de atendimento ao cliente); nome e endereço do fabricante; código de barras." $\left(3^{\circ}\right.$ Passo).

O saber fazer num certo domínio do conhecimento está vinculado ao processo de inserção do sujeito neste domínio discursivo, processo pelo qual ele vai construindo um saber dizer de natureza técnico-científica e, no caso de professores em formação, também de natureza didático-pedagógica. (MATÊNCIO, 2008, apud SANTOS, p. 350).

Nesse sentido, acreditamos que o agir da professora é fruto da apropriação dos saberes teórico-metodológicos sobre teorias da linguagem no Curso de Pedagogia, por meio do estudo de textos diversos. A leitura e reflexão sobre tais textos, sem dúvida, possibilitaram um trabalho produtivo da docente em sua prática de ensino de língua portuguesa, no Ensino Fundamental, especialmente, no que concerne às atividades de produção textual materializadas em gêneros textuais.

Entendemos que o fato de a professora propiciar aos alunos condição necessária para analisar rótulos, sem dúvida, os instiga a se engajarem na atividade proposta, agindo como sujeitos ativos e interactantes da linguagem, como bem demonstra o passo número 06 do relato da proposta apresentada:

"Cada aluno analisou o rótulo que trouxe, identificando quais os dados que estavam presentes em todos os produtos: data de validade, data de fabricação, código de barra, composição do produto (ingredientes), medida do produto, entre outros.Em seguida, cada um elaborou uma ficha com as informações do rótulo do produto escolhido por ele [...]" (Passo 06 do relato da proposta).

Atentando para o passo número 07 do relato da proposta, é possível afirmarmos que a invenção de um produto e a criação de um rótulo tratam-se de sugestões de atividades de linguagem de forma produtiva, com ações orientadas por uma dada finalidade, em detrimento de uma proposta tradicional de ensino de escrita que, geralmente, prioriza a elaboração de um texto sobre um tema proposto, com vistas à verificação do domínio das regras gramaticais, por parte dos alunos. Vejamos o que relata a professora:

"Nessa aula cada aluno escolheu uma embalagem, retirou o rótulo e criou o
seu próprio produto e rótulo, apenas aproveitando a caixa ou o formato da
embalagem. Foi pedido que eles inventassem um produto (como se fossem
os fabricantes) e utilizassem os materiais para criação de um rótulo que
deverá conter as informações já elencadas por eles e que fossem possíveis de
inserir na arte gráfica" ( Passo 07).

É importante também destacar na proposta relatada pela professora o passo número 08, o qual evidencia a culminância das atividades propostas e, em especial, a presença de destinatários reais (os colegas da turma), possibilitando aos alunos compreenderem a funcionalidade da escrita dentro de um espaço de interlocução, o que nem sempre é observado no contexto escolar:

" Socialização coletiva: cada aluno apresentou o seu produto para os colegas da turma, indicando que era um produto novo que chegou ao mercado daquela cidade. Assim, eles apresentavam o produto que criaram, mostravam 
aos alunos a embalagem (com o rótulo criado por eles) e faziam a propaganda do que "estavam vendendo" ( Passo número 08).

A atividade proposta para se trabalhar o gênero textual rótulo, ora analisada, demonstra tratar-se de um bom modelo de como orientar a escrita dos alunos e de como compreender a relevância da produção dos gêneros para a sua vida. Nas atividades constitutivas da proposta, podemos verificar: 1) clareza no conceito do gênero a ser trabalhado; 2) delimitação da finalidade que orienta a escrita do texto; 3) exploração das características do gênero rótulo; 4) esclarecimento sobre a esfera social e sobre os destinatários do texto, dentre outros fatores que mostram, simultaneamente, que a escrita não se trata de um produto pronto e acabado, mas de um processo que considera os objetivos dos interlocutores, a exploração das dimensões do gênero a ser produzido, o grau de formalidade da linguagem, entre outros elementos de uma escrita situada.

Considerando os aspectos das condições de produção elencados no relato da proposta de atividades e, sobretudo, a exploração das dimensões do gênero textual rótulo, entendemos que a proposta relatada permite aos alunos compreenderem simultaneamente que a escrita tem uma função e um sentido em cada contexto de uso da linguagem. Não se trata de uma prática de escrita sem função, destituída de qualquer valor interacional, sem autoria e sem percepção (ANTUNES, 2003), e sem o estabelecimento da relação pretendida entre a linguagem e o mundo, entre o autor e o leitor do texto.

Em uma nova perspectiva de ensino de escrita, com foco em práticas sociais situadas, bem como na teoria dos gêneros textuais, como entidades sociodiscursivas, propõe-se ao aluno não mais um texto narrativo ou descritivo, mas a escrita de um gênero textual adequado a um contexto específico de comunicação. Somente com esses cuidados "autores em processo de formação, como os alunos dos anos iniciais do Ensino Fundamental, poderão vislumbrar um sentido em produzir textos na modalidade escrita da língua" (MARCUSCHI; LEAL, p.132).

Esse sentido, a nosso ver, é contemplado pela concepção dialógica de língua, que subjaz a proposta de escrita relatada, na qual os participantes do processo interacional agem como sujeitos ativos que constroem e são construídos no texto (KOCH; ELIAS, 2010).

Isso significa dizer que os alunos, certamente, ao produzirem os rótulos, depois de uma série de atividades que os levaram a compreender a relevância e a funcionalidade de tais gêneros, bem como as suas características, produziram-nos de forma situada e não simplesmente como uma cobrança feita, no sentido de cumprir uma exigência escolar, como ocorre frequentemente em escolas do Ensino Fundamental, onde os alunos, no geral, produzem textos de livre escolha (Ex: Escreva uma redação sobre as festas juninas), sem saber por que nem para quê estão escrevendo.

As discussões apresentadas no tocante à proposta de escrita elaborada e relatada pela docente acerca do gênero rótulo revelam não só a complexidade que envolve o ensino de produção de textos, contemplando fatores linguísticos e socioculturais, mas também a importância da apropriação dos saberes linguísticos, pela professora, no Curso de Pedagogia da UFCG e dos ecos de sua formação em sua prática pedagógica na educação básica.

O trabalho producente da professora em relação à orientação da produção escrita nos mostra que, quando há condições propícias na formação inicial, os alunos-professores realizam práticas eficientes de ensino de escrita, capazes de formar verdadeiros produtores de textos e/ ou escritores competentes. Um escritor competente, conforme os PNC de Língua Portuguesa (2001), "é alguém que planeja o discurso e consequentemente o texto em função do seu objetivo e do leitor a que se destina, sem desconsiderar as características específicas do 
gênero", perfil de usuário da língua que, certamente, uma proposta como a aqui analisada é capaz de contribuir para formar.

O conhecimento da professora em relação às teorias linguísticas, em especial, sobre as teorias acerca dos gêneros textuais e da escrita situada como prática dialógica, social reverberou no trabalho com a escrita na sala de aula do Ensino Fundamental.

\section{Considerações finais}

A análise que fizemos, neste artigo, dos relatos de uma professora do Ensino Fundamental de uma escola pública do Estado da Paraíba acerca de sua formação inicial e do desenvolvimento de uma prática de ensino de escrita com foco nos gêneros textuais revelou que uma efetiva formação inicial contribui de forma consistente para a prática dos professores e, consequentemente, para a expansão das práticas de letramento dos alunos.

No caso específico da proposta de produção textual do gênero rótulo, nos anos iniciais do Ensino Fundamental, podemos observar que a devida orientação acerca do planejamento textual, considerando as condições de produção textuais (objetivo, gênero a ser produzido, tipo de linguagem, interlocutor definido etc.), é adequada à formação de alunos que possam produzir seus textos sem maiores dificuldades e de forma a conferir sentido a essa atividade, compreendida como uma prática interativa situada.

Essa perspectiva vai de encontro à crença de que para se escrever um bom texto basta apenas que o aluno faça uso de um conjunto de habilidades de natureza linguística desvinculadas dos usos reais da linguagem, da intenção de quem escreve, da definição do interlocutor provável, dos objetivos da comunicação, dentre outros fatores. Teríamos, assim, uma escrita sem sentido porque não foi produzida em uma situação efetiva de interlocução, ou seja, teríamos uma escrita mecânica e periférica, centrada nos sinais gráficos da língua.

Assim, a orientação dada aos alunos, pela professora, para a elaboração do gênero rótulo demonstra claramente os efeitos dos saberes que ela produziu durante a sua carreira profissional (formação inicial, Cursos de formação continuada, trabalho com gêneros e produção de textos no contexto escolar) e a transformação e/ou mobilização de tais saberes no dia a dia em sala de aula, visando à expansão das práticas de letramentos dos alunos.

Ampliando a discussão para as implicações da formação inicial nas práticas de ensino dos professores e focando os seus efeitos de sentido na aprendizagem dos alunos, reiteramos que é notória a necessidade de os cursos de Letras e de Pedagogia oferecerem bases epistemológicas essenciais para os futuros profissionais da área da linguagem, a exemplo das teorias acerca da escrita e dos gêneros textuais, dentro de perspectivas interacionistas e sociodiscursivas de linguagem. É fundamental que durante a formação haja um diálogo efetivo entre os aspectos conceituais, metodológicos e procedimentais, tendo em vista que a teoria pode redimensionar a prática de ensino dos professores.

\section{Referências}

ANTUNES, I. Refletindo sobre a prática de sala de aula de língua portuguesa. In: Aula de português: encontro e interação. São Paulo: Parábola, 2003, p. 19-37.

. Lutar com palavras: coesão e coerência. São Paulo: Parábola Editorial, 2005, p.199. 
BAKHTIN, M. (Volochinov). Os gêneros do discurso. In: Estética da criação verbal. São Paulo: Martins Fontes, 1997, p.237-389.

BOHN, H. I. A formação do professor de línguas: a construção de uma identidade profissional. Investigações (UFPE), Recife,( PE), v.17, n. 2, p. 97-113, 2005.

BRASIL. Ministério da Educação. Secretaria de educação Fundamental. Parâmetros Curriculares Nacionais: Língua Portuguesa 3 ed. Brasília: MEC/SEF, 2001, 43-97.

BRONCKART, J. P. As condições de produção dos textos. In: Atividades de linguagem, textos e discursos: por um interacionismo sócio-discursivo. São Paulo: Educ, 1999. p. 91-103.

BUENO, L.; LOPES, M. A. P. T.; CRISTOVÃO, V. L. L. (Orgs.). Gêneros textuais e formação inicial: uma homenagem a Malu Matêncio. Campinas, SP: Mercado de Letras, 2013 (Série Ideias sobre a linguagem), p. 384.

BUZEN, C. Da era da composição à era dos gêneros: o ensino de produção de texto no ensino médio. In: BUNZEN, C.; MENDONÇA, M. (Orgs.). Português no ensino médio e formação do professor. São Paulo; Parábola Editorial, 2006, p. 139-161.

CELANI, M. A. A. (Org.). Professores e formadores em mudança: relato de um processo de reflexão e transformação da prática docente. Campinas-SP: Mercado de Letras, 2002, p.231.

GERALDI, W. Portos de passagens. São Paulo: Martins Fontes, 1997.

KLEIMAN, A. B. (Org.). A formação do professor: perspectivas da Linguística Aplicada. Campinas, SP: Mercado de Letras, 2001, p. 115-136. (Coleção ideias sobre a linguagem).

Letramento e suas implicações para o ensino de Língua materna. Signo, Santa Cruz do Sul. v. 32, n. 53, p.1-25, 2007.

KOCH, I. V.; ELIAS, M. V. Escrita e interação. In: Ler e escrever: estratégias de produção textual. Contexto, 2010, p. 31-52.

LEAL, T.; MARCUSCHI, B. Produção de textos escritos: o que nos ensinam livros didáticos do PNLD 2007 In: COSTA V. Alfabetização e Língua Portuguesa: livros didáticos e práticas pedagógicas. Belo Horizonte: Autêntica, 2009, p. 127-150.

MARCUSCHI, L. A. Gêneros textuais: definição e funcionalidade. In: DIONISIO, A. et al (Orgs.). Gêneros Textuais e Ensino. Rio de Janeiro: Cortez, 2002. p. 19-36.

Produção textual: análise de gêneros e compreensão. São Paulo: Parábola, 2008.

MOITA LOPES, L. P. Identidades fragmentadas: a construção discursiva de raça, gênero e sexualidade em sala de aula. Campinas: Mercado de Letras, 2002.

SANTOS, L. M. A. Gêneros textuais e educação inicial de professores de Língua Inglesa sob o viés do aluno-professor. In: BUENO, L.; LOPES, M. A. P.; CRISTÓVAO, V. L. Gêneros 
textuais e formação inicial: uma homenagem à Malu Matêncio. Campinas, SP: Mercado de Letras, 2013 (Série Ideias sobre Linguagem), p. 347-356.

Recebido em: março de 2016.

Aprovado em: março 2016. 